IJJM

Ilomata International Journal of Management

P-ISSN: 2714-8971; E-ISSN:2714-8963

Vol. 1 No. 3 July 2020 pp. 113-120

https://www.ilomata.org/index.php/ijim

\title{
The Effect of Work Conflict and Work Stress on the Spirit at Work of Local Water Company (PDAM) Employee in South Solok Regency
}

\author{
Suhery $^{1}$, Agus Nurofik ${ }^{2}$ \\ Study program in Management of the Perdagangan School of Economics \\ Correspondent: agsnin@gmail.com
}

Submitted : May 8,2020 Revised : July 22, 2020 Published : July 30, 2020

\begin{abstract}
This study aims to do understanding: (1) the effect of work conflict to the spirit at work; (2) the impact of work stress on the spirit at work; (3) the effect of a work conflict and work stress to the spirit at work of PDAM employee in South Solok Regency. This research used quantitative research method by casual associative approach. The sampling technique that used was purposive sampling technique with 39 people. The method used to compile data was questionnaire method. The method that used to analyze data in this research was descriptive analysis and multiple linear regression by SPSS programs v 20.0 for windows. Based on multiple linear regression analysis, it was known that the work conflict (X1) has a significant effect on the spirit at work $(\mathrm{Y})$ with beta coefficient 0.283 . Work stress $(\mathrm{X})$ has a significant effect on the spirit at work $(\mathrm{Y})$ with beta coefficient 0.631 . This result shows that work conflict and work stress have a significant and positive effect on the work spirit of PDAM employee in South Solok Regency with sig. Score F < $5 \%(0.000 \leq 0,05)$. In conclusion, work conflict and work stress are the factors which affect the spirit at work with $61.7 \%$, while the other percentage $38.3 \%$ is affected by the other factors which are not becoming research object from this study.
\end{abstract}

Keywords : Work Conflict, Work stress, and Spirit at Work

\section{INTRODUCTION}

The prior riches for the nation is human resources. It is a factor which has an essential sector in the company beside the other factor like financial capital. Human resources must be managed very well, so the effectivity and efficiency of the company will be practiced (Hariandja, 2002). Every organization, as well as the company, will always make a significant effort to increase the employee's spirit to reach the purpose or target from the company. It also happens in The Local Water Company (PDAM) South Solok Regency. Then, the target and realization of clean water distribution in PDAM South Solok Regency can be noted in table 1 below:

Table 1

Target and Realization of Clean Water Distribution in Water Company (PDAM) South Solok Regency

\begin{tabular}{|c|c|c|c|c|c|}
\hline Year & $\begin{array}{l}\text { Distribution } \\
\text { Target }\left(\mathrm{m}^{3}\right)\end{array}$ & $\begin{array}{c}\text { Distribution } \\
\text { Realization }\left(\mathrm{m}^{3}\right)\end{array}$ & $\%$ & $\begin{array}{c}\text { Not Realized } \\
\left(\mathrm{m}^{3}\right)\end{array}$ & Percentage ( $\%)$ \\
\hline 2013 & 971.760 & 519.822 & 53,5 & 451.938 & 46,5 \\
\hline 2014 & 975.917 & 548.621 & 56,2 & 427.350 & 43,8 \\
\hline 2015 & 988.760 & 427.243 & 43,2 & 561.517 & 56,8 \\
\hline 2016 & 1.014 .836 & 483.290 & 48,8 & 507.108 & 51,2 \\
\hline 2017 & 1.114 .936 & 491.258 & 49,2 & 506.683 & 50.8 \\
\hline
\end{tabular}

Source: secondary data of PDAM South Solok in 2018 
Recruitment Analysis on Employee Performance With Variable Control As Moderating On Manufacturing Company

Setiawan, Wakhyuni, \& Siregar

Based on table 1, the distribution realization of clean water in 2013-2017 are always getting fluctuation. Because of the fluctuation from the distribution target and realization of clean water, the company must be able to cope with this problem to reach the predetermined target.

There are several causes of the unsuccessful reached of the clean water distribution target. Firstly, there is limited available pipe stock, even pipe deficiency in clean water distribution. Secondly, the employees do not want to work if there is no incentive from this company, and unfortunately that this company often overdue for giving the incentive to the employee, and this can be caused of decreasing employee's spirit at work. Thirdly, there is leakage in the pipes in several spots. Moreover, the employees are lack of responsibility to solve the problem in water distribution. Several areas that have pipe leakage can be noted in table 2 below:

Table 2

\section{Data of the Areas that get pipe leakage PDAM South Solok in 2018}

\begin{tabular}{|c|l|c|c|}
\hline No & Area & Total of leakage & Duration of leakage handling (day) \\
\hline 1 & Lundang & 2 & 4 \\
\hline 2 & Pasir Talang & 1 & 2 \\
\hline 3 & Lakuak & 1 & 2 \\
\hline 4 & Kuti Anyir & 1 & 2 \\
\hline 5 & Sangir & 1 & 2 \\
\hline
\end{tabular}

Source : secondary of PDAM South Solok in 2018

Based on the data above, five areas get pipe leakages, the leading cause from this leakage is the impact of water-pressure fluctuation, so it makes the pipes trembling and got leakage.

Based on the information from the interview to the PDAM employee South Solok Regency, it shows that the dominant problem which affects their spirit at work can be observed from the high number of their absence (without any reason, coming late, and leaving within a particular time) and the high number of labour turn-over. The number of absence is considered in this problem because the workload is too heavy so the employees tend to do not go to work without any reason. The high number of labour turn-over is caused by the conflict between the employees that happened all the times, and it makes the other employees cannot bear it in work.

The number of the absence of PDAM employee South Solok in January-May 2018 can be shown on the following table below.

Table 3. Absence Data of PDAM Employee South Solok in January-October 2018

\begin{tabular}{|l|c|c|c|c|}
\hline \multicolumn{1}{|c|}{ Month } & Total of the employee & Without any reason & Leave & Coming late \\
\hline January & 40 & 6 & 5 & 13 \\
\hline February & 40 & 9 & 9 & 20 \\
\hline March & 40 & 16 & 11 & 27 \\
\hline April & 40 & 12 & 17 & 20 \\
\hline May & 40 & 5 & 19 & 29 \\
\hline June & 40 & 10 & 11 & 15 \\
\hline July & 40 & 9 & 17 & 21 \\
\hline August & 40 & 11 & 6 & 10 \\
\hline September & 40 & 9 & 10 & 7 \\
\hline October & 40 & 9 & 8 & 9 \\
\hline
\end{tabular}

Source: Secondary Data of PDAM South Solok in 2018

Based on table 3 above, it shows that the condition of spirit still not gets the optimum position, because there are still many employees who skip and the high number of coming late. 
Recruitment Analysis on Employee Performance With Variable Control As Moderating On Manufacturing Company

Setiawan, Wakhyuni, \& Siregar

Based on the problem statement above and the information from the Human Research Development of PDAM South Solok, decreasing spirit at work is caused by two dominant factors: work conflict and work stress of the employee. The dominant conflict that happened in PDAM South Solok Regency is conflict between the employees themself, they lack of support each other to finish some works as a team. They lack of awareness and supporting each other during work, dropping between employees in order to strengthen their position in front of the boss, and having different perception about something in meeting and there is no one wanting to budge.

The other dominant factor is work stress. This is a conflict that needs to be noticed. Actually, stress does not give a negative impact on the employee. Proportional pressure can be a motivator to more productive in working; this kind of stress usually called eustress. But, if the stress is not proportional or overstress, it can affect the employee's performances. A lot of works that are piling up and pressure from their boss to finish the jobs on time are one of the stress causes of PDAM South Solok's employee.

Based on the background that already explained above, the author decided to choose a title The Effects of Work Conflict and Work Stress on the Spirit at Work of Water Company (PDAM) Employee in South Solok Regency.

Based on the introduction, the author formulated the problems in this research as follows; Firstly, how is the effect of work conflict to the work spirit? Secondly, How is the impact of work stress on the work spirit? Thirdly, How is the effect of a work conflict and work stress to of PDAM South Solok Employee?

This study aimed to understand and analyze the effect of work conflict to the work spirit, the impact of work stress to the work spirit, and the effect of a work conflict and work stress to the work spirit of PDAM South Solok Employee.

According to Tohardi (2006), spirit at work is a common term which involves the needs outside work such as salary, security, and position in society. Syukria (2004) maintains that spirit at work is spiritual or behavior condition of the individual employee and the groups that raise deep happiness oh their self to work more active and consistent with reaching the purposes that already stated of the company. Here are some indicators of spirit at work stated by Nitisemito (2002): (a) Increased employee productivity; (b) Less number of absence; (c) Declining Labour Turn-Over, and (d) There is no anxiety or lack of it.

Rahim (2011) said that conflict is an interactive process which manifested in such things like incompatibility, disagreement, or irregularities both within individuals and social interactions such as individuals, groups or organizations. Mitchell, dkk (2000) explained that conflict or contention in particular condition could identify environmentally and resource management processes that are not running effectively, sharpen ideas, even can explain the misunderstanding. Conflict of interest between members of the organization or within the community is natural. According to Fitriana (2013), the indicators of conflict at work are: (a) Coordination; (b) Communication; (c) Dependence on task implementation; (5) Different perception; and )(6) Work competition.

Rivai (2009) stated that work stress is tension condition that creates a physical or psychical imbalance, effect to the emotion, thought process and employee condition. According to Mangkunegara (2008), work stress is a feeling depressed experienced by the employee in dealing with work. This is occurred from the syndrome, for instance, unstable emotion, feeling uneasy, 
Recruitment Analysis on Employee Performance With Variable Control As Moderating On

Manufacturing Company

Setiawan, Wakhyuni, \& Siregar

likes to be alone, hard to sleep, excessive smoking, hard to relax, anxious, tense, nervous, increased blood pressure, and having digestive disorder. The indicators of work stress, according to Pujaatmaka (2008), can be divided into three aspects: (a) Indicators on psychologic; (b) Indicators on physic; and (c) Indicators on behavior.

\section{METHOD}

The method that used in this research is quantitative by using the casual associative approach. The study took place in Local Water Company (PDAM) South Solok that located in Raya Pasir Talang's street - Muaralabuh, South Solok. The study conducted starting in February until the data was collected. The sample of this research is all of the employees in PDAM South Solok Regency, which numbered 39 people.

Measurement scale that was used in this research is the Likert measurement scale technique. The technique to collect data was using a questionnaire, interview, and documentation. The author used linear and multiple regression analysis to analyze the data.

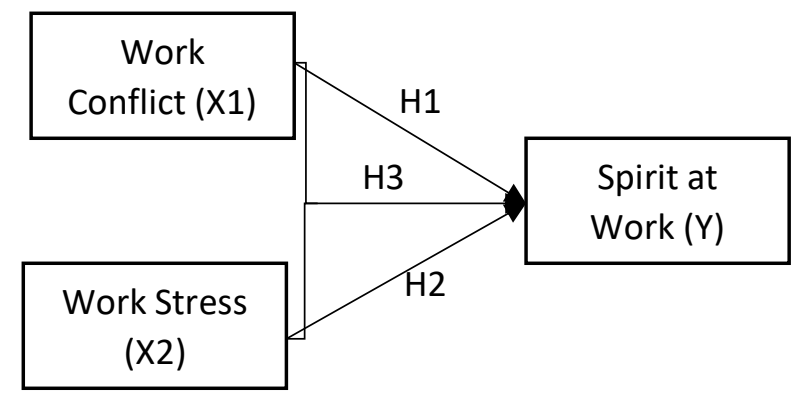

Based on the theoretical basis and conceptual framework above, so the hypotheses of this research are:

H1: Work conflict has a positive effect on the spirit at work of PDAM South Solok Regency's employee

H2: Work stress has a positive effect on the spirit at work of PDAM South Solok Regency's employee

H3: Work conflict and Work stress has a positive effect on the spirit at work of PDAM South Solok Regency's employee

\section{RESULT AND DISCUSSION}

From the collected data during research to 39 respondents, it was shown several views of individual identity based on the age, 10 people are 19-21 years old with percentage 25,6\%, 13 people are 21-30 years old with percentage 33,3\%, 10 people are $31-40$ years old with percentage $25,6 \%$, and the last is 6 people are more than 40 years old with percentage $15,4 \%$.

The respondents based on the sex which appropriate with the data from PDAM South Solok Regency shows that male respondent is 24 people $(61,5 \%)$ and the female is 15 people $(38,5 \%)$.

Based on the level of education, the employee who became respondents in this research have different title. There are 4 people who graduated from magister degree (10,3\%), 14 people graduated from undergraduate degree $(35,9 \%), 11$ people graduated from Diploma $(28,2 \%)$, and 10 people graduated from Senior High School (25,6\%). 
Recruitment Analysis on Employee Performance With Variable Control As Moderating On Manufacturing Company

Setiawan, Wakhyuni, \& Siregar

The employee conditions from the work period are 6 employees have worked less than 1 year are 6 people (15,4\%), between $1-5$ work period are 17 people (43,6\%), 6-10 years are 12 people $(30,8 \%)$, and more than 10 years are 4 people $(10,3 \%)$.

Table 4. Multiple Linear Regression Analysis Result

\begin{tabular}{|c|c|c|}
\hline \multirow{2}{*}{ Variable } & \multicolumn{2}{|l|}{ Unstandardized Coefficients } \\
\cline { 2 - 3 } & B & Std. Error \\
\hline Constanta (a) & 11.437 & 4.198 \\
\hline Work conflict (X1) & 0.283 & 0.122 \\
\hline Work stress (X2) & 0.631 & 0.511 \\
\hline
\end{tabular}

Source : Data Processing Result in 2019

Based on table 4, relation style of free variable Conflict at work $\left(\mathrm{X}_{1}\right)$ and work stress $\left(\mathrm{X}_{2}\right)$ to the spirit at work $(\mathrm{Y})$, where the number of Constanta (a) is 11.437 so the equality as follows:

$$
\begin{aligned}
& \mathbf{Y}=\mathbf{a}+\mathbf{b} 1 \mathbf{X} 1+\mathbf{b} 2 \mathbf{X} 2+\mathbf{e} \\
& \mathbf{Y}=11.437+0.283 \mathrm{X} 1+0.631 \mathrm{X} 2+\mathrm{e}
\end{aligned}
$$

That regression equality can be explained, Constanta to Work Conflict (X1) and the work environment (X2) is 11.437. There is positive effect between regression coefficient of work conflict (X1) 0.283, if the other independent variable is constant and work conflict (X1) increases one unit so the spirit at work will increase as significant as 0.283 . There is positive effect between regression coefficient variable of work stress (X2) 0.631, if the other independent level is constant and work stress variable (X2) get increasing one unit so the spirit at work will increase as big as 0.631

Table 5. The result of determination coefficient $\left(\mathbf{R}^{2}\right)$

\begin{tabular}{|l|c|r|r|r|}
\hline Model & $\mathrm{R}$ & \multicolumn{1}{|c|}{$\begin{array}{c}\text { Adjusted R } \\
\text { Square }\end{array}$} & \multicolumn{1}{|c|}{$\begin{array}{c}\text { Std. Error of the } \\
\text { Square }\end{array}$} & \multicolumn{1}{|c|}{ Estimate } \\
\hline 1 & .798 & .637 & .617 & 3.82900 \\
\hline
\end{tabular}

Source : Data Processing Result in 2019

Based on table 5 , it is obtained the result of $\mathrm{R} 2$ score is 0.617 . This means that work conflict and work stress are the factors that affect to spirit at work with significant percentage $61.7 \%$, whereas the other $38.3 \%$ is affected by the other factors that are not an object in this research.

Table 6. t-Test Result

\begin{tabular}{|c|c|c|c|c|c|}
\hline Variable & t-statistics & t table & Sig. & $\boldsymbol{\alpha}$ & Result \\
\hline Work conflict (X1) & 2.322 & 1.684 & 0.026 & 0.05 & H1 accepted \\
\hline Work stress (X2) & 3.449 & 1.684 & 0.001 & 0.05 & H2 accepted \\
\hline
\end{tabular}

Source : Data Processing Output in 2019 
Recruitment Analysis on Employee Performance With Variable Control As Moderating On

Manufacturing Company

Setiawan, Wakhyuni, \& Siregar

Based on table 6, it is obtained the score of tstatistics work conflict variable (X1) is 2.322 and table 1.684 with the number of sig 0.026 so $\mathrm{H}_{1}$ is accepted. The result shows that work conflict has significant effect partially to the spirit at work. The score of tstatistics work stress variable is 3.449 and table with the value of $\operatorname{sig} 0.001$, so $\mathrm{H}_{2}$ is accepted. The result shows that work stress has a significant effect to the spirit at work.

Table 7. F-Test Result

\begin{tabular}{|r|r|r|l|}
\hline F-statistics & F-table & Sig. & Conclusion \\
\hline 31.586 & 2.85 & 0.000 & H3 is accepted \\
\hline
\end{tabular}

Based on table 7 , it is obtained $F_{\text {statistics }} 31.586>F_{\text {table }}(2.85)$ with sig $0.000 \leq 0,05$, so $\mathrm{H}_{3}$ is accepted and $\mathrm{H}_{\mathrm{o}}$ is denied. The result shows that work conflict and work stress all together affect positively and significantly to the work spirit to the PDAM South Solok employee.

\section{RESULT AND DISCUSSION}

\section{The Effect of Work Conflict on Spirit at Work of the employee in PDAM South Solok Regency.}

The finding research of work conflict variable $\left(\mathrm{X}_{1}\right)$ which has positive score showed that there is an effect of a positive and significant relation between work conflict on the spirit at work of the employee in PDAM south Solok Regency. The positive sign showed that if the work conflict is minimum, so the spirit at work of the employee in PDAM South Solok Regency will increase. The result of t-statistics work conflict variable ( $\left.\mathrm{X}_{1}\right)$ is 2.322 with sig 0.026 so $\mathrm{H}_{1}$ is accepted. Based on this research, as a whole, it can be said that work conflict $\left(\mathrm{X}_{1}\right)$ has positive and significant effect to the spirit at work $(\mathrm{Y})$ of the employee in PDAM South Solok Regency.

Robbins (2009) suggested that conflict is an interactional process which happened because of inexpediency between two premises (point of view) which affected by involved side whether positive effect or negative effect. The theory that explained the relation of work conflict to the spirit at work refer to the theory of Winardi (2004) which explained that positive work conflict will spur on the high spirit of work to reach the main/ together purpose.

This finding research is in line with the research that has already conducted by Indriati (2013), from that result it can be obtained that work conflict has positive and significant effect to the spirit of employee's work.

\section{The Effect of Work Stress on the Spirit at Work of the Employee in PDAM South Solok Regency}

The result of work stress variable (X2) which has positive value showed that there is positive and significant relation effect between work stress on the spirit at work of the employee in PDAM South Solok Regency. The positive sign showed that if the work stress is minimum so the spirit at work of the employee in PDAM South Solok Regency will increase. The result of tstatistics work stress variable is 3.449 with sig 0.001 , so $\mathrm{H} 2$ is accepted.

Based on the result in this research, as a whole, it can be said that work stress has positive and significant effect to the work spirit of the employee in PDAM South Solok Regency. 
Recruitment Analysis on Employee Performance With Variable Control As Moderating On

Manufacturing Company

Setiawan, Wakhyuni, \& Siregar

This finding is in line with the research that had already conducted by Fauji (2013), from that research was obtained that work stress has positive and significant effect to the spirit at work of the employee.

\section{The Effect of Work Conflict and Work Stress to the Spirit at Work of the Employee in PDAM South Solok Regency}

Based on the result of F-test, it was obtained that Fstatistics $31.586>$ Ftable 2.85 with sig 0.000 $\leq 0,05$ so $\mathrm{H}_{3}$ is accepted and $\mathrm{H}_{\mathrm{o}}$ is denied. The result of $\mathrm{R}^{2}$ is 0.617 . This means that work conflict and work stress are the factors that affect the spirit at work with percentage $61.7 \%$, whereas the other $38.3 \%$ is affected by the other factors that were not the object from this research.

In the main of those, it can be said that work conflict and work stress all together affect positively and significantly to the spirit at work of the employee in PDAM South Solok Regency. This finding is in line with the research that had already conducted by Septiani (2008), from her research it was obtained that work conflict and work stress have positive and significant effect to the spirit at work of the employee.

\section{CONCLUSION}

Based on the result of analyzing the data, there is a positive and significant relation between work conflict $\left(\mathrm{X}_{1}\right)$ to the spirit at work $(\mathrm{Y})$ of the employee in PDAM South Solok Regency. The result of tstatistics work conflict $\left(\mathrm{X}_{1}\right)$ is 2.322 with sig 0.026 so $\mathrm{H}_{1}$ is accepted. There is a positive and significant relation between work stress $\left(\mathrm{X}_{2}\right)$ to the spirit at work $(\mathrm{Y})$ of the employee in PDAM South Solok Regency. The result of tstatistics work stress variable is 3.449 with sig 0.001 , so $\mathrm{H}_{2}$ is accepted. There is a positive and significant relation between work conflict ( $\left.\mathrm{X}_{1}\right)$ and work stress $\left(\mathrm{X}_{2}\right)$ to the spirit at work $(\mathrm{Y})$ of the employee in PDAM South Solok Regency. Based on the result of $F$ test, it was obtained that $F_{\text {statistics }} 31.586>F_{\text {table }} 2.85$ with sig $0.000 \leq 0,05$ so $\mathrm{H}_{3}$ is accepted and $H_{o}$ is denied. The result of $\mathrm{R}^{2}$ is 0.617 . This means that work conflict and work stress are the factors that affect spirit at work with percentage $61.7 \%$, whereas the other $38.3 \%$ is affected by the other factors that were not the object of this research.

The company should give particular therapy like counselling or go to a psychiatrist or guidance from the boss for the employee who tends to be sensitive and easy to feel offended. It will help them to solve their problem.

The company should give a particular time to the employee to make a good relationship with each other like outbound activity. Outbound is a holiday activity that benefitted nature superiority to build team cooperation and self-development through the educative game such as arum jeram, motivation training, and paintball. The purpose is giving awareness to the employee to take care of each other and be able to apply it in a company as an approach to make team cooperation is keeping and more cohesive.

To the problem like absence especially to the employee who absence without any reason, the company should make new polices like applying punishment through salary cutting or hard warning to the employee to make them more responsible with their work. This aims to make sure that they have high attendance percentage and become a good figure to the others. 
Recruitment Analysis on Employee Performance With Variable Control As Moderating On

Manufacturing Company

Setiawan, Wakhyuni, \& Siregar

\section{REFERENCES}

Arikunto, Suharsimi. (2010). Prosedur penelitian. Jakarta: Rineke cipta.

Azwar. (2007). MetodePenelitian. Yogyakarta: Pustaka Belajar.

Fitriana. (2013). Persepsi Insemtif dengan Konflik. Jakarta: Erlangga.

Ghozali, Imam. (2005). Aplikasi Analisis Multivariate dengan Program SPSS Edisi 3. Semarang: Universitas Diponegoro.

Hasibuan, Malayu S.P. (2013). Manajemen Sumber Daya Manusia. Jakarta: Bumi Aksara.

Hariandja, Marihot T.E. (2002). Manajemen Sumber Daya Manusia. Jakarta: Grasindo

Mangkunegara. (2008). Manajemen Sumber Daya Manusia. Bandung: PT. Remaja Rosda Karya.

Mitchell, Bruce, dkk. (2000). Pengelolaan Sumber Daya dan Lingkungan. Yogyakarta: Gadjah Mada University.

Nitisemito, Alex S. (2002). Manajemen Personalia. Jakarta: Ghalia Indonesia.

Pujaatmaka. (2008). Manajemen Sumber Daya Manusia. Yogyakarta: Andi.

Robbins, Stephen P. (2009). Perilaku Organisasi. Jakarta: Salemba Empat.

Rahim, Afzalur. (2011). Managing Conflict in Organizations. 4th Edition (New Jersey: Transaction Publishers.

Rivai. (2009). Manajemen Sumber Daya Manusia Untuk Perusahaan Dari Teori Ke Praktik. Jakarta:

PT. Raja Grafindo Persada.

Sugiyono. (2004). Memahami Metode Penelitian Kuantitatif, Kualitatif, dan R\&D. Bandung: Alfabeta.

Septiani, Hayfa. (2008).Pengaruh Konflik Kerja Terhadap Semangat Kerja Karyawan Pada CV Usaha Jaya Banjarmasin. Kalimantan Selatan. Jurnal Ekonomi. Fakulta Ekonomi. Universitas Nusantara PGRI Kediri.

Sofyan, M. (2019). Faktor-Faktor yang Mempengaruhi Jiwa Kewirausahaan. JMK (Jurnal Manajemen dan Kewirausahaan), 4(3), 194-204. doi:10.32503/jmk.v4i3.586

Syukria. (2004). Kontribusi Iklim Kerja Sama dan Semangat Kerja Terhadap Kinerja Guru. Jurnal Manajemen. Padang: SMKN 1.

Tohardi. (2006). Pemahaman Praktis Manajemen Sumber Daya Manusia, Bandung: Mandar Maju.

Winardi. (2004). Manajemen Perilaku Organisasi cetakan ke 2. Jakarta: Kencana Media Group. 